\title{
Infrared Spectra of Asphalts
}

\author{
Burton D. Beitchman
}

(March 18, 1959)

\begin{abstract}
A procedure for preparing thin films of airblown asphalts and a spectroscopic study of such films throughout the infrared region of 2.5 to 15 microns are described. The relationship of transmittance of several absorption bands with the durability of the asphalt is discussed. Exposure to ultraviolet radiation produced changes in transmittance at four wavelengths which, in a series of asphalts studied, showed statistically significant correlations with durability.
\end{abstract}

\section{Introduction}

Roofing asphalts vary greatly in durability depending upon the source of the particular asphalt. One method for measuring durability that is currently being used is based upon the time required for development of cracks over 50 percent of the surface of an asphalt film when such a film is exposed to natural weatbering conditions or to radiation from a carbon are in an accelerated weathering test. ${ }^{1}$

Stewart ${ }^{2}$ recently reported an infrared study of components from three asphalts before and after natural weathering. These asphalts varied in durability, and Stewart pointed out chemical properties in the components that might be associated with the durabilities of the asphalts.

An infrared study of the whole asphalt appeared desirable since the general characteristics of asphalts could be readily indicated without resorting to a fractionation procedure. The use of whole asphalt permits easy study of changes effected in the asphalt by exposure to heat, ultraviolet, and other forms of radiation.

Schweyer ${ }^{3}$ has reported a study of films of asphalt residua. These films were too thick $(0.1 \mathrm{~mm})$ to permit study below $8 \mu$ and he therefore resorted to solution techniques to obtain absorption data in this region.

The procedure described in this paper offers a simple means for studying whole asphalt.

\section{Procedures}

An infrared study was made of 28 airblown roofing asphalts from widely different sources. The softening points ${ }^{4}$ of these asphalts ranged from $205^{\circ} \mathrm{F}$ to $241^{\circ} \mathrm{F}$ and the penetrations ${ }^{5}$ at $77^{\circ} \mathrm{F}$ from 11 to 23 .

Films of asphalt were prepared by placing a small drop of molten asphalt on a sheet of cellophane film. A second sheet of cellophane was

\footnotetext{
1 S. H. Greenfeld, A STM Bull. 193, 50 (1953)

2 J. E. Stewart, J. Research NBS 58, 265 (1957), RP2759.

3 H. E. Schweyer, Anal. Chem., 30, 205 (1958).

4 A STM Method D36-26.

5 ASTM Method D5-52.
}

placed over the asphalt, and the two sheets were then quickly placed in a hydraulic press in which the upper platen was maintained at approximately $90^{\circ}$ C.1,6 A pressure of 16,000 psi was applied to the sheets and maintained for about 20 sec. The sheets were removed from the press, and the thickness of the asphalt film and two cellophane sheets was measured with a dial-thickness gage having a foot about $1 / 4$ in. in diameter with which thickness could be estimated to the nearest 0.01 mil. By determining the thickness of the two cellophane sheets, the thickness of the asphalt film was obtained by difference. To ensure greater reproducibility of results, areas of nearly uniform thickness were predetermined and indicated by marking the boundaries of these areas on the cellophane film. The asphalt films were obtained in various thicknesses ranging from about 0.5 to 2.5 mils. By allowing the asphalt film and two sheets of cellophane to soak in distilled water for several minutes, one of the cellophane sheets could be removed easily. The asphalt film and the remaining cellophane sheet were soaked again in distilled water for several minutes in order to remove the second cellophane film. The asphalt film was mounted on a film support made of cardboard or plastic which had a rectangular opening, $1.4 \times 3.5 \mathrm{~cm}$. The predetermined area of nearly uniform thickness was placed over the opening. After allowing the asphalt films to dry, infrared spectra were taken.

The films prepared by this method were not perfectly uniform in thickness and thickness ranges have been recorded in this paper rather than average values. This must be considered a limitation where the transmittance $(\tau)^{7}$ of the unexposed films have been used for quantitative comparisons. The changes produced at four wavelengths by exposure to ultraviolet radiation did not appear to be dependent upon film thickness over the range of thickness employed. Thus, correlations which were made of changes in absorption with durability do not have this limitation imposed upon them.

\footnotetext{
$6 \mathrm{~S}, \mathrm{H}$, Greenfeld reported the use of a press for making films with a range of ${ }^{6} \mathrm{~S}$. H. Greenfeld reported the use of a press for making films with a range of
5 to 50 mils thickness, NBS Building Materials and Structures Report 147 (1956). 7 The symbol $\tau$ has been used for optical transmittance in accordance with the publication ASA Z 10.6 (1948) of the American Society of Mechanical Engineers.
} 


\section{Results}

The infrared spectra of films of asphalts obtained from widely different sources showed a marked similarity in their absorption characteristics. All the asphalts had absorption bands at the same or very nearly the same wavelengths and their spectra differed primarily in the transmittance values of some of these bands.

The structural groupings which appeared to be present in all the asphalts examined are hydroxyl, $-\mathrm{CH}_{2}-, \mathrm{C}-\mathrm{CH}_{3}$, carbonyl, $-\left(\mathrm{CH}_{2}\right)_{4}-$ and aromatic rings. There were also absorption bands which indicated aromatic substituents or fused rings. Other weak but reproducible bands were noted at $8.66 \mu\left(1,155 \mathrm{~cm}^{-1}\right)$ and $9.71 \mu(1,030$ $\left.\mathrm{cm}^{-1}\right)$. The structural assignments given to the various bands are listed in table 1 . These are for the most part, the same groupings identified by Stewart ${ }^{2}$ in fractions of three asphalts.

Figures 1 and 2 show representative spectra of two of the asphalt films. Table 1 gives values of $\log 1 / \tau$, determined by the base-line method, for absorption bands from the spectra of seven asphalts. The less durable asphalts appear to have slightly more hydroxyl absorption than the more durable asphalts. The $\mathrm{C}-\mathrm{CH}_{3}$ band intensity at $7.25 \mu$ $\left(1,380 \mathrm{~cm}^{-1}\right)$ seems also to show a relationship to durability. Uncertainties in the average thickness produce corresponding uncertainties in the transmittance. In the case of the hydroxyl band at $2.91 \mu\left(3,430 \mathrm{~cm}^{-1}\right)$, the uncertainties in average thickness do not invalidate the observed general correlation with durability. However, in the case of the band at $7.25 \mu\left(1,380 \mathrm{~cm}^{-1}\right)$, uncertainties in the value of $\log 1 / \tau$ may be sufficient to obscure any correlation with durability.

Duplicate samples of asphalts $\mathrm{A}$ and $\mathrm{F}$ are included in table 1 to demonstrate the reproducibility of the spectra. The relation of film thickness to absorption intensities appears to follow the Beer-Lambert Law as illustrated in figure 3.

Figures 4 and 5 show spectra of two asphalt films

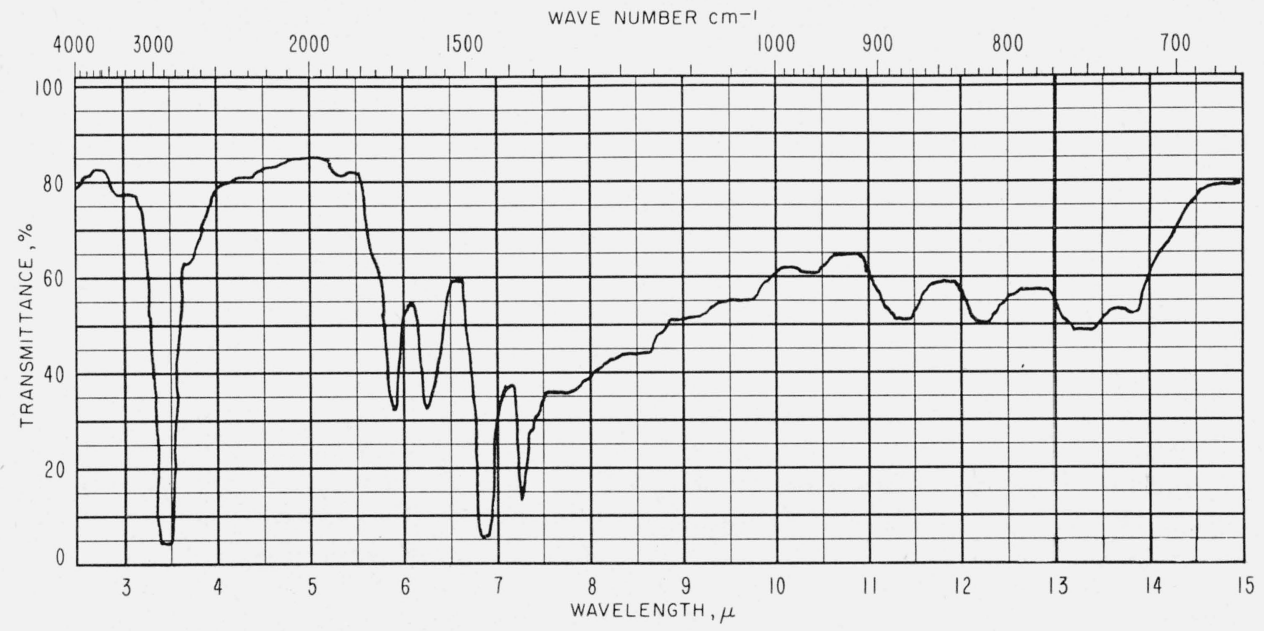

FIGURE 1. Infrared spectrum of asphalt D (1.8 to 2.1 mils thick).

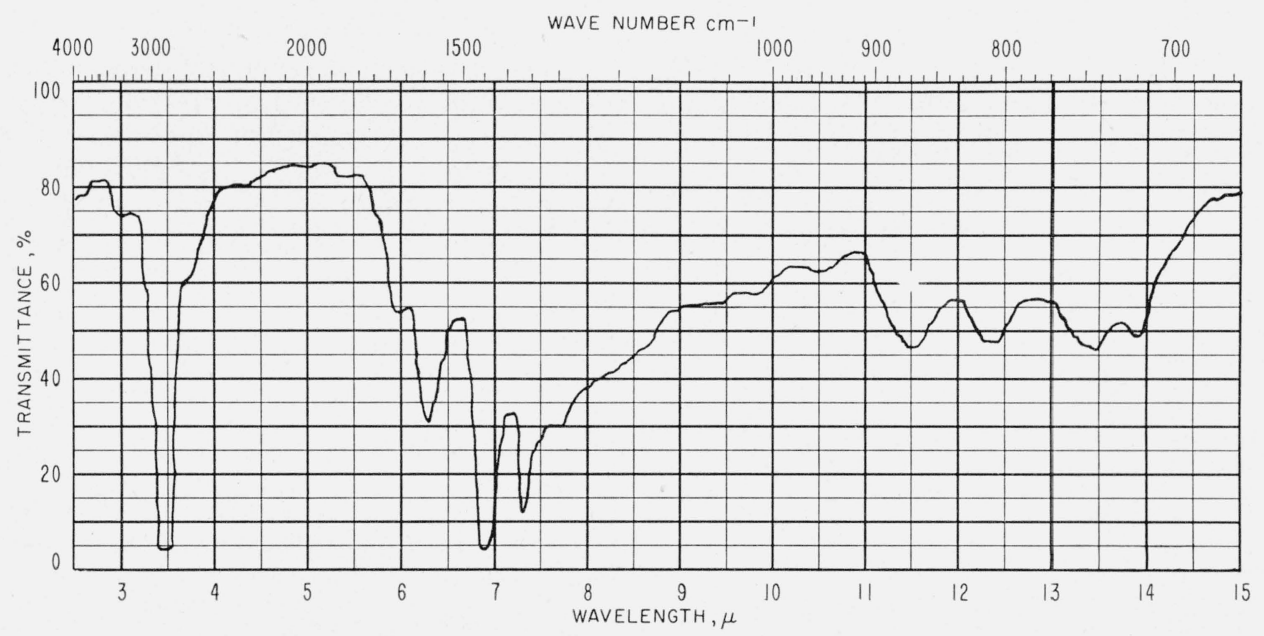

Figure 2. Infrared spectrum of asphalt B (1.9 to 2.3 mils thick). 
TABLE 1. Log $1 / \tau$ values obtained from the infrared spectra of asphalt films

\begin{tabular}{|c|c|c|c|c|c|c|c|c|c|c|c|c|c|c|c|c|c|}
\hline \multicolumn{5}{|c|}{$\begin{array}{l}\text { Frequency } \\
\text { Wavelength }\end{array}$} & $\begin{array}{r}3,430 \\
2.91\end{array}$ & $\begin{array}{r}2,960 \\
3.38\end{array}$ & $\begin{array}{r}1,700 \\
5.88\end{array}$ & $\begin{array}{r}1,600 \\
6.25\end{array}$ & $\begin{array}{r}1,470 \\
6.80\end{array}$ & $\begin{array}{r}1,380 \\
7.25\end{array}$ & $\begin{array}{r}1,155 \\
8.66\end{array}$ & $\begin{array}{r}1,030 \\
9.71\end{array}$ & $\begin{array}{r}961 \\
10.41\end{array}$ & $\begin{array}{r}866 \\
11.55\end{array}$ & $\begin{array}{r}811 \\
12.33\end{array}$ & $\begin{array}{r}750 \\
13.33\end{array}$ & $\begin{array}{r}720 \\
13.89\end{array}$ \\
\hline Assigned st & ucturalg & roups. & & 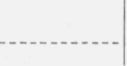 & $-\mathrm{OH}$ & $-\mathrm{CH}_{2}-\mathrm{CH}_{3}$ & $\mathrm{C}=\mathrm{O}$ & $\begin{array}{l}\text { Aro- } \\
\text { matic }\end{array}$ & $-\mathrm{CH}_{2}-$ & $\mathrm{C}-\mathrm{CH}_{3}$ & & $\begin{array}{l}\mathrm{S}=\mathrm{O} \\
\text { or } \mathrm{SiO}\end{array}$ & $\begin{array}{l}\text { Naph- } \\
\text { thenic }\end{array}$ & \multicolumn{3}{|c|}{$\begin{array}{l}\text { Aromatic } \\
\text { substitution }\end{array}$} & $-\left(\mathrm{CH}_{2}\right)_{4}-$ \\
\hline Asphalt & $\begin{array}{l}\text { Soften- } \\
\text { ing } \\
\text { point a }\end{array}$ & $\begin{array}{c}\text { Penetra- } \\
\text { tion at } \\
77^{\circ} \mathrm{F} \text { a }\end{array}$ & $\begin{array}{l}\text { Dura- } \\
\text { bility b }\end{array}$ & $\begin{array}{l}\text { Thickness } \\
\text { of film }\end{array}$ & \multicolumn{13}{|c|}{ Log $1 / \tau$ values (determined by base-line method) } \\
\hline $\begin{array}{l}\mathrm{E} \\
\mathrm{C} \\
\mathrm{G} \\
\mathrm{D} \\
\mathrm{D}\end{array}$ & $\begin{array}{l}{ }^{\circ} F \\
231 \\
230 \\
226 \\
216 \\
220\end{array}$ & $\begin{array}{l}18 \\
18 \\
13 \\
12 \\
13\end{array}$ & $\begin{array}{r}\text { Days } \\
23 \\
45 \\
51 \\
66 \\
73\end{array}$ & $\begin{array}{c}\text { Mils } \\
1.8 \text { to } 2.0 \\
1.7 \text { to } 1.9 \\
1.7 \text { to } 1.9 \\
1.8 \text { to } 2.1 \\
1.6 \text { to } 1.8\end{array}$ & $\begin{array}{r}0.065 \\
.050 \\
.041 \\
.019 \\
.030\end{array}$ & $\begin{array}{l}\text { (c) } \\
\text { (c) } \\
\text { (c) } \\
\text { (c) }\end{array}$ & $\begin{array}{l}0.127 \\
.059 \\
.074 \\
.305 \\
.071\end{array}$ & $\begin{array}{r}0.206 \\
.153 \\
.200 \\
.240 \\
.171\end{array}$ & $\begin{array}{r}0.948 \\
1.040 \\
1.040 \\
1.102 \\
.942\end{array}$ & $\begin{array}{l}0.518 \\
.542 \\
.478 \\
.476 \\
.415\end{array}$ & $\begin{array}{r}0.034 \\
.034 \\
.042 \\
.044 \\
.035\end{array}$ & $\begin{array}{r}0.021 \\
.024 \\
.026 \\
.030 \\
.012\end{array}$ & $\begin{array}{r}0.020 \\
.016 \\
.019 \\
.019 \\
.017\end{array}$ & $\begin{array}{r}0.061 \\
.039 \\
.096 \\
.085 \\
.078\end{array}$ & $\begin{array}{r}0.066 \\
.060 \\
.068 \\
.062 \\
.070\end{array}$ & $\begin{array}{r}0.110 \\
.114 \\
.116 \\
.024 \\
.117\end{array}$ & $\begin{array}{l}0.072 \\
.079 \\
.080 \\
.131 \\
.100\end{array}$ \\
\hline $\begin{array}{l}\mathrm{A} \\
\mathrm{B} \\
\mathrm{F} \\
\mathrm{F}\end{array}$ & $\begin{array}{l}220 \\
229 \\
221 \\
221\end{array}$ & $\begin{array}{l}13 \\
14.5 \\
19 \\
19\end{array}$ & $\begin{array}{l}73 \\
73 \\
75 \\
75\end{array}$ & $\begin{array}{l}1.6 \text { to } 1.8 \\
1.5 \text { to } 1.9 \\
1.7 \text { to } 2.0 \\
1.7 \text { to } 2.0\end{array}$ & $\begin{array}{l}.032 \\
.025 \\
.033 \\
.031\end{array}$ & $\begin{array}{l}\text { (c) } \\
\text { (c) } \\
\text { (c) } \\
\text { (c) }\end{array}$ & $\begin{array}{l}.071 \\
.074 \\
.036 \\
.038\end{array}$ & $\begin{array}{l}.166 \\
.200 \\
.192 \\
.208\end{array}$ & $\begin{array}{l}.977 \\
1.182 \\
1.068 \\
1.064\end{array}$ & $\begin{array}{l}.409 \\
.411 \\
.458 \\
.480\end{array}$ & $\begin{array}{l}.028 \\
.026 \\
.038 \\
.036\end{array}$ & $\begin{array}{l}.018 \\
.026 \\
.020 \\
.014\end{array}$ & $\begin{array}{l}.013 \\
.012 \\
.020 \\
.020\end{array}$ & $\begin{array}{l}.072 \\
.100 \\
.083 \\
.082\end{array}$ & $\begin{array}{l}.060 \\
.061 \\
.068 \\
.076\end{array}$ & $\begin{array}{l}.101 \\
.108 \\
.114 \\
.123\end{array}$ & $\begin{array}{l}.089 \\
.115 \\
.108 \\
.100\end{array}$ \\
\hline
\end{tabular}

a Data obtained from asphalt suppliers.

burability by accelerated weathering. Data obtained by J. Falzone and S. Ishihara, Research Associates for Asphalt Roofing Industry Bureau, NBS.

- Intense absorption.

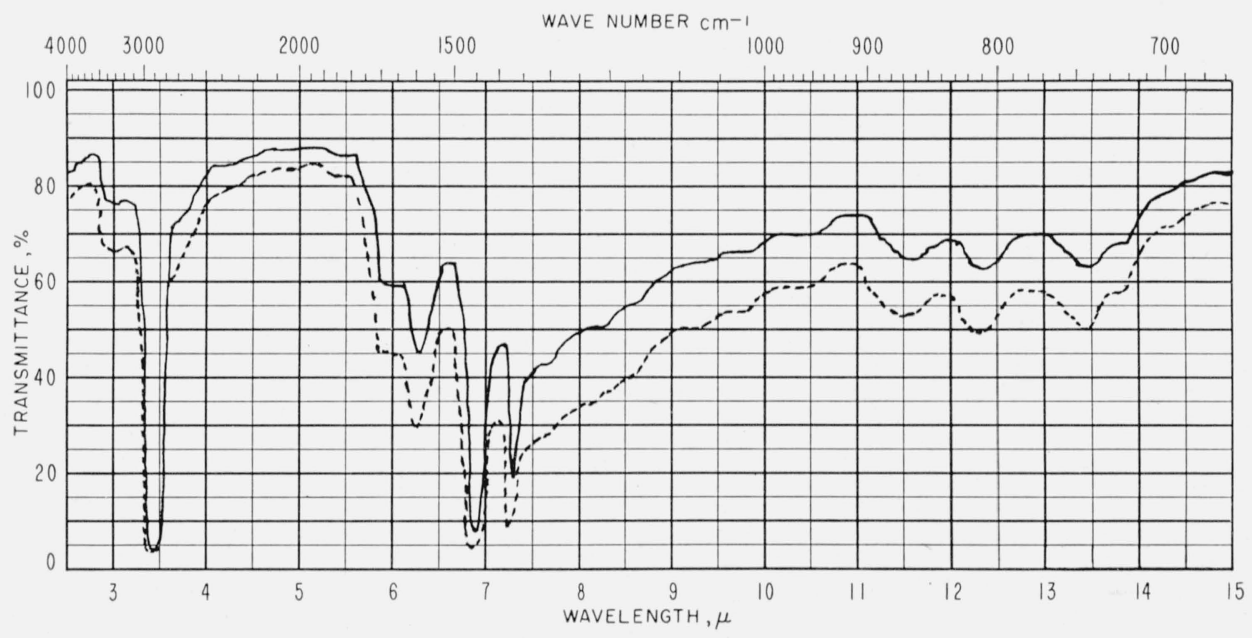

Figure 3. Infrared spectra of asphalt E.

-1.1 to 1.3 mils thick, - - -1.8 to 2.0 mils thick.

before and after exposure to radiation from a carbon arc for $19.5 \mathrm{hr}$. These spectra show characteristic changes that were also observed in other asphalts. Table 2 shows some of the changes produced in the values of $\log 1 / \tau$ of four asphalts. Changes in the values of $\log 1 / \tau$ for bands at $3.38 \mu\left(2,960 \mathrm{~cm}^{-1}\right)$ and $6.80 \mu\left(1,470 \mathrm{~cm}^{-1}\right)$ are not shown in table 2 (the films used for illustrative purposes in this table were too thick to show the changes in these regions). All the asphalts increased in carbonyl and hydroxyl absorption and the less durable asphalts generally showed a greater increase in carbonyl and hydroxyl absorption and absorption at $8.66 \mu\left(1,155 \mathrm{~cm}^{-1}\right)$ and $9.71 \mu\left(1,030 \mathrm{~cm}^{-1}\right)$ than the more durable asphalts.

Plots of durability values versus changes in log $1 / \tau$ at $5.88 \mu\left(1,700 \mathrm{~cm}^{-1}\right), 2.91 \mu\left(3,430 \mathrm{~cm}^{-1}\right), 8.66 \mu$ $\left(1,155 \mathrm{~cm}^{-1}\right)$, and $9.71 \mu\left(1,030 \mathrm{~cm}^{-1}\right)$ appeared to show inverse relationships. Because of the small magnitude of these changes at the latter three wavelengths, statistical correlations based on their rankings were used rather than the actual values, and these were compared with the rankings of durabilities. On the basis of values obtained from spectra of 11 asphalts, Spearman's rank correlation coefficients were calculated for all four correlations of durability with changes in the value of $\log 1 / \tau$ (table 3).

These correlation coefficients are significant at the 1 percent level for 9 degrees of freedom. As for the correlation of durability with changes in transmittance at $5.88 \mu$, a linear relation could be assumed to exist between durability and the reciprocal of changes in $\log 1 / \tau$. The product-moment correlation coefficient was calculated to be 0.779 , which is significant at the 1 percent level for the number of samples involved. 


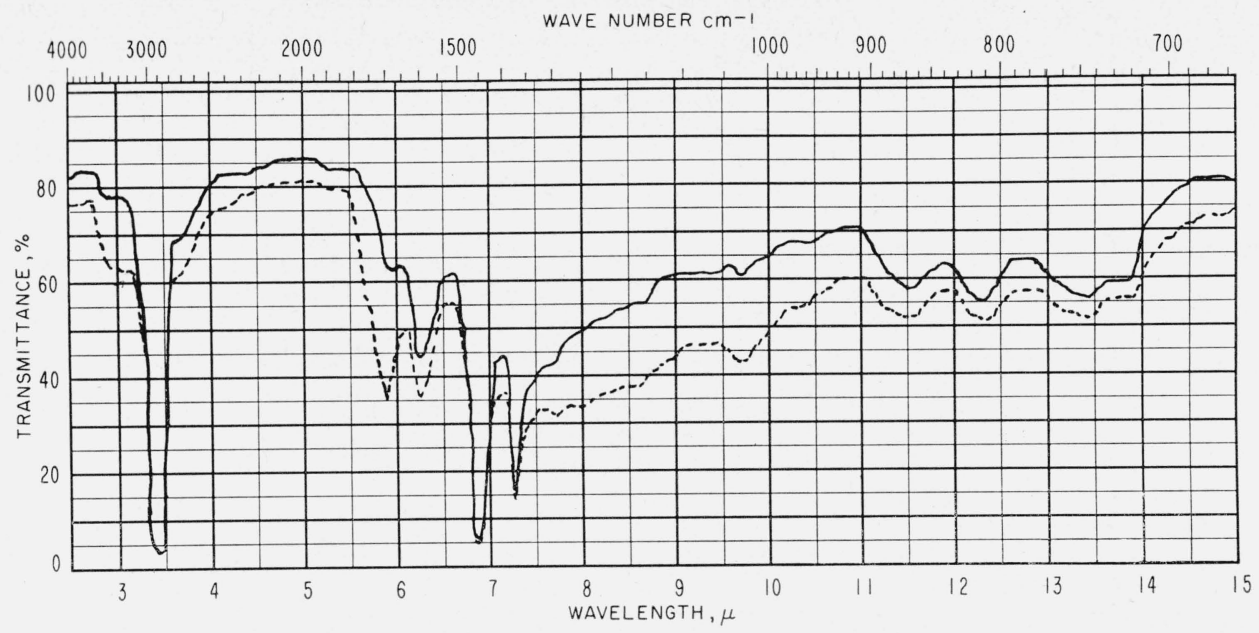

FIGURE 4. Infrared spectra of asphalt U (1.15 to 1.55 mils thick). - before exposure, - - - after exposure.

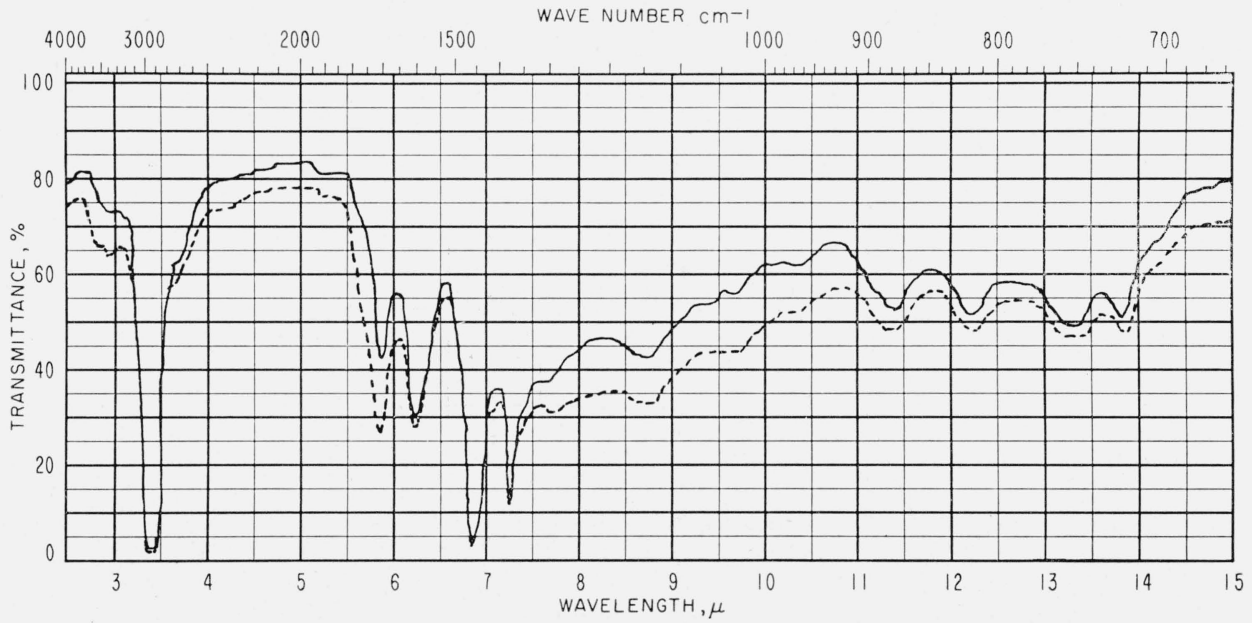

Figure 5. Infrared spectra of asphalt V (1.81 to 2.09 mils thick).

- before exposure, - - - after exposure.

TABLE 2. Changes produced in $\log 1 / \tau$ values of asphalts by ultraviolet exposure

\begin{tabular}{|c|c|c|c|c|c|c|c|c|c|c|c|c|c|c|c|}
\hline \multicolumn{5}{|c|}{$\begin{array}{l}\text { Frequency } \\
\text { Wavelength }\end{array}$} & $\begin{array}{r}3,430 \\
2.91\end{array}$ & $\begin{array}{r}1,700 \\
5.88\end{array}$ & $\begin{array}{r}1,600 \\
6.25\end{array}$ & $\begin{array}{r}1,380 \\
7.25\end{array}$ & $\begin{array}{r}1,155 \\
8.66\end{array}$ & $\begin{array}{r}1,030 \\
9.71\end{array}$ & $\begin{array}{r}961 \\
10.41\end{array}$ & $\begin{array}{r}866 \\
11.55\end{array}$ & $\begin{array}{r}811 \\
12.33\end{array}$ & $\begin{array}{r}750 \\
13.33\end{array}$ & \multirow{2}{*}{$\begin{array}{r}720 \\
13.89 \\
\left(\mathrm{CH}_{2}\right)_{4}-\end{array}$} \\
\hline \multicolumn{5}{|c|}{ Assigned structural groups.. } & $-\mathrm{OH}$ & $\mathrm{C}=\mathrm{O}$ & $\begin{array}{l}\text { Aro- } \\
\text { matic }\end{array}$ & $\mathrm{C}-\mathrm{CH}_{3}$ & & $\begin{array}{l}\mathrm{C}-\mathrm{O} \\
\mathrm{S}=\mathrm{O} \\
\text { or } \mathrm{SiO}\end{array}$ & $\begin{array}{l}\text { Naph- } \\
\text { thenic }\end{array}$ & \multicolumn{3}{|c|}{ Aromatic substitution } & \\
\hline Asphalt & $\begin{array}{l}\text { Soft- } \\
\text { ening } \\
\text { point }\end{array}$ & $\begin{array}{c}\text { Penetra- } \\
\text { tion at } \\
77^{\circ} \mathrm{Fa}^{-}\end{array}$ & $\begin{array}{l}\text { Dura- } \\
\text { bility b }\end{array}$ & $\begin{array}{l}\text { Thickness } \\
\text { of film }\end{array}$ & \multicolumn{11}{|c|}{$\log 1 / \tau$ values (determined by base-line method) } \\
\hline & $\circ F$ & & Days & Mils & & & & & & & & & & & \\
\hline $\begin{array}{l}\text { Q } \\
\mathrm{Q}^{\mathrm{c}}-\ldots+\cdots\end{array}$ & 227 & 18 & 35 & $\begin{array}{l}2.2 \text { to } 2.6 \\
2.2 \text { to } 2.6\end{array}$ & $\begin{array}{r}0.055 \\
.130\end{array}$ & $\begin{array}{r}0.262 \\
.565\end{array}$ & $\begin{array}{r}0.421 \\
.558\end{array}$ & & $\begin{array}{r}0.036 \\
.144\end{array}$ & $\begin{array}{r}0.028 \\
.150\end{array}$ & $\begin{array}{r}0.008 \\
.019\end{array}$ & $\begin{array}{r}0.071 \\
.066\end{array}$ & $\begin{array}{r}0.084 \\
.076\end{array}$ & $\begin{array}{r}0.096 \\
.105\end{array}$ & $\begin{array}{r}0.101 \\
.125\end{array}$ \\
\hline $\begin{array}{l}R \\
R c \ldots \ldots\end{array}$ & 224 & 21 & 38 & $\begin{array}{l}2.2 \text { to } 2.5 \\
2.2 \text { to } 2.5\end{array}$ & $\begin{array}{l}.019 \\
.034\end{array}$ & $\begin{array}{l}.135 \\
.325\end{array}$ & $\begin{array}{l}.284 \\
.301\end{array}$ & $\begin{array}{r}0.60 \\
.54\end{array}$ & $\begin{array}{l}.026 \\
.040\end{array}$ & $\begin{array}{l}.05 \\
.10\end{array}$ & $\begin{array}{l}.008 \\
.020\end{array}$ & $\begin{array}{l}.067 \\
.084\end{array}$ & $\begin{array}{l}.037 \\
.061\end{array}$ & $\begin{array}{l}.090 \\
.105\end{array}$ & $\begin{array}{l}.094 \\
.110\end{array}$ \\
\hline $\mathrm{S}_{-}$ & 222 & 19 & 50 & $\begin{array}{l}2.3 \text { to } 2.6 \\
2.3 \text { to } 2.6\end{array}$ & $\begin{array}{l}.031 \\
.061\end{array}$ & $\begin{array}{l}.153 \\
.343\end{array}$ & $\begin{array}{l}.362 \\
.354\end{array}$ & $\begin{array}{l}.64 \\
.59\end{array}$ & $\begin{array}{l}.038 \\
.030\end{array}$ & $\begin{array}{l}.027 \\
.098\end{array}$ & $\begin{array}{l}.019 \\
.010\end{array}$ & $\begin{array}{l}.072 \\
.042\end{array}$ & $\begin{array}{l}.039 \\
.043\end{array}$ & $\begin{array}{l}.076 \\
.090\end{array}$ & $\begin{array}{l}.086 \\
.099\end{array}$ \\
\hline T. & 223 & 23 & 72 & $\begin{array}{l}\text { 2. } 30 \text { to } 2.56 \\
\text { 2. } 30 \text { to } 2.56\end{array}$ & $\begin{array}{l}.045 \\
.050\end{array}$ & $\begin{array}{l}.205 \\
.321\end{array}$ & $\begin{array}{l}.377 \\
.407\end{array}$ & $\begin{array}{l}.58 \\
.58\end{array}$ & $\begin{array}{l}.036 \\
.036\end{array}$ & $\begin{array}{l}.032 \\
.068\end{array}$ & $\begin{array}{l}.017 \\
.024\end{array}$ & $\begin{array}{l}.062 \\
.050\end{array}$ & $\begin{array}{l}.079 \\
.066\end{array}$ & $\begin{array}{l}.109 \\
.119\end{array}$ & $\begin{array}{l}.132 \\
.114\end{array}$ \\
\hline
\end{tabular}

a Data obtained from asphalt suppliers

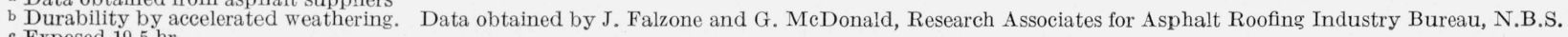

c Exposed 19.5 hr. 
TABLE 3. Correlations of durability with changes in $\log 1 / \tau$ at certain wavelengths

\begin{tabular}{c|r}
\hline \hline $\begin{array}{c}\text { Wavelength (wave } \\
\text { number) }\end{array}$ & $\begin{array}{c}\text { Spearman's } \\
\text { rank cor- } \\
\text { relation } \\
\text { coefficient }\end{array}$ \\
\hline $5.88 \mu\left(1,700 \mathrm{~cm}^{-1}\right)$ & 0.782 \\
$8.66 \mu\left(1,155 \mathrm{~cm}^{-1}\right)$ & .945 \\
$9.71 \mu\left(1,030 \mathrm{~cm}^{-1}\right)$ & .836 \\
$2.91 \mu\left(3,430 \mathrm{~cm}^{-1}\right)$ & .815 \\
\hline
\end{tabular}

\section{Discussion of Results and Conclusions}

A simple technique for studying the structure of whole asphalts by infrared spectroscopy has been developed. The use of this method on 28 asphalts, which come from widely different sources and which vary greatly in durability as roof coatings, showed the asphalts to be remarkably similar in absorption characteristics. In the unexposed asphalt the only absorption band that showed some degree of correlation with durability was that produced by hydroxyl absorption. In general, the less durable asphalts exhibited stronger hydroxyl absorption than the more durable asphalts. The intensities of the band at $7.25 \mu\left(1,380 \mathrm{~cm}^{-1}\right)$ attributed to $\mathrm{C}-\mathrm{CH}_{3}$ absorption appeared to show some correlation with durability, but because of variations in film thickness, uncertainties existed which tended to obscure the significance of such a correlation.

The exposure of asphalt films to a carbon arc produced oxidative changes, which were largely the formation of carbonyl and hydroxyl groups and also changes in absorption at $9.71 \mu\left(1,030 \mathrm{~cm}^{-1}\right)$ and 8.66 $\mu\left(1,155 \mathrm{~cm}^{-1}\right)$. The durabilities of the asphalts showed inverse relationships with changes in absorption at each of these wavelengths. By calculating Spearman's rank correlation coefficients, each of the correlations was shown to be statistically significant. A product-moment correlation coefficient was calculated for the correlation of durabilities with the changes of $\log 1 / \tau$ at $5.88 \mu\left(1,700 \mathrm{~cm}^{-1}\right)$. This correlation coefficient also indicated that the correlation was highly significant.

The absorption band near $9.71 \mu\left(1,030 \mathrm{~cm}^{-1}\right)$ was observed in fractions of asphalt by Stewart. ${ }^{2}$ Stewart considered $\mathrm{C}-\mathrm{O}, \mathrm{S}=\mathrm{O}$, or $\mathrm{SiO}$ as the most likely groups to be responsible for this absorption. He also observed that weakening of this band in exposed asphaltic fractions appeared to be consistent with oxidation of sulfoxides to sulfones. The asphalt films exposed to the carbon arc in this study, however, showed increases in the band near $9.71 \mu$. The correlation of durabilities with changes in carbonyl and hydroxyl absorption and also with changes in values of $\log 1 / \tau$ at $8.66 \mu\left(1,155 \mathrm{~cm}^{-1}\right)$ and $9.71 \mu$ $\left(1,030 \mathrm{~cm}^{-1}\right)$ suggest that the changes at these wavelengths may have been caused by changes in concentration of $\mathrm{C}-\mathrm{O}$ linkages.

The author is grateful for the assistance given by Victoria E. Sanchez and Dwight G. Moore, Jr., in obtaining spectra and thanks members of the Floor, Roof, and Wall Coverings Section for their cooperation. Statistical analyses of the correlations indicated in this paper were made by Hsien Hsiang $\mathrm{Ku}$.

Washington, D.C. (Paper 63A2-14). 



\section{Publications of the National Bureau of Standards}

\section{Selected Abstracts}

A coulometric-titration coulometer, S. W. Smith and J. K. Taylor, J. Research NBS 63C, No. 1, 65 (1959).

A highly precise coulometer is described which permits integration of currents of 100 coulombs or more with a precision of about 1 part in 100,000 . The current to be integrated oxidizes hydroquinone in an electrolysis cell, producing quinone and acid. The quinone is then reduced by constantcurrent coulometric-titration, the end point being indicated by $p \mathrm{H}$ measurements.

\section{A refined $\mathbf{X}$-band microwave microcalorimeter,} G. F. Engin, J., Research NBS 63C, No. 1, $77^{\prime}$ (1959).

The microcalorimetric method for evaluation of the efficiency and substitution error of a bolometer mount proposed by Macpherson and Kerns has been the object of further study and refinement at the Boulder Laboratories of the National Bureau of Standards, and an improved instrument based on this technique has been recently placed in operation. The new microcalorimeter design features: (1) Greatly improved ambient temperature control, permitting higher sensitivity and resolution, (2) improved d-c instrumentation, (3) improved mechanical construction giving better repeatability, (4) relocation of the thermopile such that it is no longer attached directly to the bolometer mount, thus providing flexibility in the choice of termination, and (5) a more comprehensive treatment of this calorimetric substitution or equivalence error. These features permit the determination of the effective efficiency of a bolometer mount to an accuracy of better than 0.2 percent.

\section{A tilting air-lubricated piston gage for pressures below one-half inch of mercury, U. O. Hutton, J. Research NBS 63C, No. 1, 47 (1959).}

A description is given of a tilting dead weight piston gage constructed at the National Bureau of Standards for ranges of differential pressure up to about 0.5 inch of mercury. A resolution of better than one part in a hundred thousand of full scale has been obtained by use of the toolmaker's sine bar method of angle measurement. The scale is a linear function of the sine. The instrument can be calibrated from basic measurements of length and weight, is rugged, and mav be constructed in almost any laboratory mechanical shop. Sources of possible errors in reading are discussed in detail. Comparative tests with certain other gages or manometers are cited wherein linearity was found to be within one part in 10,000 and agreement within 2.5 parts in 10,000 . The uses of the gage are briefly discussed.

Compact multianvil wedge type high-pressure apparatus, E. C. Lloyd, U. O. Hutton, and D. P. Johnson, J. Research NBS 63C, No. 1, 59 (1959).

The paper describes apparatus for generating high pressures by application of anvil forces against each face of a solid polyhedron. The equipment constructed utilizes a tetrahedron of pvrophyllite and four tungsten carbide anvils as described earlier by H. T. Hall. External force is applied to one of the anvils and wedge reaction forces act on the other anvils, permitting the equipment to be used in a conventional hydraulic press. Examples of results of use of the equipment are given. Success of the design has been shown by the repeated generation of pressures in excess of 100,000 atmospheres (and higher pressures are anticipated), indicating that large existing presses might be used to generate pressures of this order in volumes of several cubic inches. For higher pressures a two-stage multianvil apparatus is proposed in which the second-stage anvils are embedded in a large pyrophyllite tetrahedron to obtain necessary supporting forces.

Comparison of absolute intensities of [OI] $55 \%$ in the auroral and subauroral zones, F. E. Roach, J. W. McCaulley, and C. M. Purdy, J. Research NBS 63D, No. 1, 19 (1959).

The distribution of 5577 zenith intensities is compared for Fritz Peak, Colorado, in the subauroral zone and Thule, Greenland, near the geomagnetic pole. At the Colorado station, the absolute intensity is bright enough to permit visual detection during 2 percent of the time; at the Greenland station 27 percent of the time. The distribution curves have a general similarity, suggesting a phenomenonological similarity in the excitation mechanisms at the two stations.

Compressible turbulent boundary layers with heat transfer and pressure gradient in flow direction, A. Walz, J. Research NBS 63B, No. 1, 53 (1959)

Derivation of a method of approximate calculation using integral conditions obtained from basic partial differential equations for viscous compressible fluid. Generalization of semiempirical laws for turbulent wall friction and dissipation for application in the compressible case with heat transfer.

Creep of cold-drawn nickel, W. D. Jenkins and C. R. Johnson, J.Research NBS 63C, No.1, 1 (1959).

Creep tests were made in tension under constant loads at temperatures of $300^{\circ}, 700^{\circ}, 900^{\circ}$, and $1200^{\circ} \mathrm{F}$ on specimens of nickel initially cold-drawn 40-percent reduction in area. The relations between the experimental results and the equations proposed by other investigators are evaluated and discussed in some detail. None of these equations was found to be suitable to express or predict the creep-test results of this investigation with high accuracy as changes in structure accompanying the creep processes are inadequately described by these equations. However, conformance to the parabolic strain-time law was obtained over limited ranges of stresses and strains. The effects of colddrawing on the creep properties are discussed, and certain etching techniques were employed that gave evidence of the presence and movement of dislocations in the structures.

Current and potential relations for the cathodic protection of steel in a high resistivity environment, W. J. Schwerdtfeger, J. Research NBS 63C, No. 1, 37 (1959).

In order to evaluate criteria for the cathodic protection of bare low carbon steel in a high resistivity environment, specimens were exposed in the laboratory for a period of two months to a soil having a resistivity of about 20,000 ohm-cm. Emphasis was put on the protective potential criterion $(-0.77 \mathrm{v}$ with reference to a saturated calomel half-cell) with and without IR drop caused by the protective current included in the potential. A criterion based on current density indicated by the cathodic polarization curve was also studied. The current required for protection was about three times the magnitude of the corrosion current; therefore, the corrosion reaction was either under anodic control or an equivalent type of control which was caused by high resistance at anodic areas. The best degree of protection was achieved on the specimen controlled at -0.77 $\mathrm{v}$ without the IR drop. Applied current indicated by the break (change-in-slope) in the cathodic polarization curve agreed quite well with the actual current required to maintain polarization at $-0.77 \mathrm{v}$ 
Diffraction of electromagnetic waves by smooth obstacles for grazing angles, J. R. Wait and A. M. Conda, J. Research NBS 63D, No. 2, 181 (1959).

The diffraction of electromagnetic waves by a convex cylindrical surface is considered. Attention is confined primarily to the region near the light-shadow boundary. The complexintegral representation for the field is utilized to obtain a correction to the Kirchoff theory. Numerical results are presented which illustrate the influence of surface curvature and polarization on the diffraction pattern. Good agreement with the experimental results of Bachynski and Neugebauer is obtained. The effect of finite conductivity is also considered.

Effect of light and water on the degradation of asphalt, L. R. Kleinschmidt and H. R. Snoke, J. Research NBS 63C, No. 1, 31 (1959).

The effects of light only and of light and water on the degradation of asphalt by accelerated and outdoor exposures were determined. Specimens exposed to light only gained weight and developed a surface film of material insoluble in common asphalt solvents. Specimens exposed to light and water lost weight because of the leaching out of water-soluble degradation products. Since the loss in weight was greater for the thicker coatings, it was concluded that a migration of light degradable components occurred in specimens exposed to light and water.

Electron beam magnetometer, L. Marton, L. B. Leder, J. W. Coleman, and D. C. Schubert, J. Research NBS 63C, No. 1, 69 (1959).

A theoretical investigation of the electron optics of an electron beam deflection method for detecting small magnetic fields is presented. It is shown that remarkably high sensitivity can be reached. A laboratory model of such a magnetometer was constructed, and it was demonstrated that the theoretical estimate of sensitivity $3 \times 10^{-5}$ amperes per oersted, could be attained in practice. A discussion of the possible improvements which could extend the sensitivity of the device is also given.

Lens design: A new approach, O. N. Stavroudis, J. Research NBS 63B, No. 1, 31 (1959).

This paper is concerned with the problem of defining and calculating the aberrations of an optical system and their application to lens design. A method of defining total aberrations is presented which involves the derivatives of image space ray coordinates with respect to object space ray coordinates. Their calculation makes use of the properties of Jacobian matrices and Herzberger's fundamental optical invariant.

Origin of $[\mathrm{OI}] 55 \mathrm{~g}$ in the airglow and the aurora, F. E. Roach, J. W. MrCaulley, and E. Marovich, J. Research NBS 63D, No. 1, 15 (1959).

The distribution of 5577 zenith intensities at stations in the subauroral zone is found to be unimodal with no discontinuity at the visual threshold. This is interpreted as evidence that 5577 airglow and 5577 aurora may have a common origin.

Relations between summation methods and integral transformations, W. Greub, J. Research NBS 63B, No. 1, 1 (1959).

Relations between the Lototsky method of summation and those of Borel, Euler, and Knopp are obtained by associating an integral transformation with the series transformation.

Tables of transport integrals: A supplement, W. M. Rogers, W. J. Hall, and R. L. Powell, J. Research NBS 63B, No. 1, 23 (1959).

Tables of values of the transport integrals, defined by

$$
J_{n}(x)=\int_{0}^{x} \frac{e^{z} z^{n} d z}{\left(e^{z}-1\right)^{2}}
$$

were published in a previous National Bureau of Standards Circular for values of $n$ from 2 through 17 . In this report values are given for the integrals where $n$ is 18 and 20 and where $x$ ranges from 0.2 to 50.0 in steps of 0.2 .

Transmission and reflection by a parallel wire grid, M. T. Decker, J. Research NBS 63D, No. 1, 87 (1959).

A comparison is made at $\mathrm{X}$-band frequencies of the theoretical and measured transmission and reflection coefficients for a parallel wire grid. The methods used are applicable to the measurement of these factors for various building materials.

\section{Non-Bureau Publications}

\section{An improved 8-hydroxyquinoline method for the determination of magnesium oxide in portland cement. $H$. A. Berman, ASTM Bull. No. 237, 51 (Apr. 1959).}

To determine $\mathrm{MgO}$ in portland cement, a rapid method (optional in Federal and ASTM Specifications) involves precipitation of the $\mathrm{Mg}$ salt of 8-hydroxyquinoline, which is then filtered, acidified, and titrated with $\mathrm{KBrO}_{3}$. This method gives high results near the specification limit $(4-5 \%$ $\mathrm{MgO}$ ), poor operator reproducibility, and excessive specification "failures" which require time-consuming rechecks by the referee ammonium phosphate method. The high results are due to coprecipitation of excess 8-hydroxyquinoline with the $\mathrm{Mg}$ salt at high concentrations. Low results are obtained at low reagent or $\mathrm{Mg}$ concentrations $(0-2 \% \mathrm{MgO})$. Precipitation conditions were studied. Although they can be adjusted to minimize the errors, this approach is not practicable when the $\mathrm{MgO}$ content of the sample is not known in advance. However, a double precipitation procedure with 8-hydroxyquinoline has been developed which is as accurate and reproducible as the ammonium phosphate method and considerably faster. A constant quantity of 8-hydroxyquinoline is added to a definite volume of solution containing the $\mathrm{Mg}(400 \mathrm{ml})$, the precipitate is filtered, redissolved, and reprecipitated with $1 \mathrm{ml}$. of the reagent solution. The improved procedure is proposed as a referee method. After separation of $\mathrm{SiO}_{2}, \mathrm{Fe}_{2} \mathrm{O}_{3}, \mathrm{Al}_{2} \mathrm{O}_{3}, \mathrm{Mn}_{2} \mathrm{O}_{3}$ and $\mathrm{CaO}$, six cement samples can be analyzed for $\mathrm{MgO}$ in 2.5 hours.

Degradation of cellulose acetate films, W. K. Wilson and B. W. Forshee, SPE Journal 15, No. 2. 146 (Feb. 1959).

The degradation of several cellulose acetate film formulations has been studied in connection with a project on the development of specifications for a laminating film for the protection of archival documents. An unplasticized film and a typical plasticized film were studied over a temperature range from $60^{\circ} \mathrm{C}$ to $177^{\circ} \mathrm{C}$ in oxygen and in nitrogen. The degradation was principally oxidative in nature and was followed by measuring the change in intrinsic viscosity, which was correlated with changes in the stress-strain diagram. A study of the degradation of several commercial films at $124^{\circ} \mathrm{C}$ showed that they varied widely in their stability. For highest stability, plasticizers containing an aliphatic ether linkage should be avoided and acid acceptors and antioxidants should be incorporated into the film formulation.

Formation of ozone from atomic oxygen at low temperatures, R. A. Ruehrwein and J. S. Hashman, J. Chem. Phys. 30, No. 3, 823 (Mar. 1959).

Oxygen was passed through an electrodeless discharge and was condensed, either alone or mixed with diluent gases, at liquid helium temperature. On warming through a temperature range of $13-30^{\circ} \mathrm{K}$. the deposits darkened considerably in color (blue) and the amount of ozone formed was deter- 
mined. From these observations it was concluded that about 11 percent is the maximum concentration of oxygen atoms that can be trapped in the solid and that the reaction $\mathrm{O}+\mathrm{O}_{2}=\mathrm{O}_{3}$ has an activation energy of $1 \mathrm{kcal}$. At high concentrations of oxygen atoms in the discharged gas, ozone was formed upon condensation by the predominant reactions (1) $\mathrm{O}+\mathrm{O}=\mathrm{O}_{2}$ and (2) $\mathrm{O}+\mathrm{O}_{2}=\mathrm{O}_{3}$. The experimentally observed conversion to ozone of 58 percent agreed well with that calculated from a rate law with $\mathrm{K}_{1}=\mathrm{K}_{2}$.

Note on measurement of sine-wave response of lenses, R. E. Stephens, J. Opt. Soc. Am. 49, No. 4, 413 (Apr. 1959).

In the procedure of Lamberts for measuring the sine-wave response of a lens the phase angle is measured by determining its cosine. For angles less than 45 degrees the precision achieved by measuring the cosine is less than is possible by measuring the sine. By displacing the scanning slit onequarter wavelength transversely data for computing the sine of the phase angle may be obtained.

Selection of glasses for three-color achromats, R. E. Stephens, J.Opt. Soc. Am. 49, No. 4, 398 (Apr. 1959).

If two thin lens elements of two different glasses are combined into a thin two-element system, then the chromatic properties of the system may be described by the effective values of $\left.V \mid V=(N-1) /\left(N_{F}-N_{C}\right)\right]$, and $P\left[P=\left(\Delta N / N_{F}-N_{C}\right)\right]$. The effective value, $\bar{P}$, is a linear function of $\bar{V}$. On a graph of $P$ versus $V$, the straight line drawn through the points for two glasses is the locus of all possible effective values of $V$ and $P$ for combinations of these two glasses. By means of such a graph the effective value $\bar{P}$ for a combination of two glasses may be matched to $P$ of a third glass whose $V$ differs from $\bar{V}$ by a useful amount. An achromatic lens system of the three glasses may then be computed, which will have a common focal length for three wavelengths.

Some radiological applications of gamma ray transport theory, M. J. Berger and L. V. Spencer, Radiation Research 10, No. 5, 552 (May 1959).

Gamma ray transport theory is applied to the calculation of energy dissipation in bounded water media under conditions approximating those found in radiological problems. A combination of analytical, numerical and random sampling techniques is used. Two typical situations are considered: a medium in which an isotropic source of radiation is distributed, and a medium irradiated by an external source consisting of a narrow pencil-beam. The spatial pattern of energy dissipation is worked out in detail for sources emitting 1.28-Mev photons.

Thermal decomposition of poly (vinyl chloride), R. R. Stromberg, S. Straus, and B. G. Achhammer, J. Polymer Sci. 35, No. 129, 355 (Mar. 1959).

Poly(vinyl chloride) polymerized using gamma radiation, benzoyl peroxide, and 2,2'-azo-bis(isobutyronitrile) as initiators, was thermally decomposed in vacuo. The gaseous decomposition products as analyzed by mass spectrometry consist primarily of hydrogen chloride for decomposition temperatures below approximately $300^{\circ} \mathrm{C}$. At temperatures approximating $400^{\circ} \mathrm{C}$ various hydrocarbons are evolved along with the hydrogen chloride. Energetic considerations are discussed and a temperature dependent activation energy is described. A free radical mechanism for the dehydrochlorination reaction that appears consistent with the reaction rate data is postulated.

\section{Other NBS Publications}

Journal of Research, Section 63B, No. 1, JulySeptember 1959. 75 cents.

Relations between summation methods and integral transformations. Werner Greub. (See above abstracts).

On a modification of Watson's lemma. F. Oberhettinger.

Principal submatrices of a full-rowed non-negative matrix. K. Goldberg.

Zeros of certain polynominals. A. J. Goldman.

Tables of transport integrals: A supplement. William M. Rogers, William J. Hall, and Robert L. Powell. (See above abstracts).

Lens design: A new approach. Orestes N. Stavroudis. (See above abstracts).

Analytical integration of the differential equation for water storage. Vujica M. Yevdjevich.

Compressible turbulent boundary layers with heat transfer and pressure gradient in flow direction. Alfred Walz. (See above abstracts).

\section{Journal of Research, Section 63C, No. 1, July-} September 1959 . 75 cents.

Creep of cold-drawn nickel. William D. Jenkins and Carl R. Johnson. (See above abstracts).

Friction and endurance of prelubricated and unlubricated ball bearings at high speeds and extreme temperatures. Hobart S. White.
Effect of light and water on the degradation of asphalt. L. R. Kleinschmidt and H. R. Snoke. (See above abstracts).

Current and potential relations for the cathodic protection of steel in a high resistivity environment. W. J. Schwerdtfeger. (See above abstracts).

A tilting air-lubricated piston gage for pressures below one-half inch of mercury. U. O. Hutton. (See above abstracts).

Compact multianvil wedge type high-pressure apparatus. E. C. Lloyd, U. O. Hutton, and D. P. Johnson. (See above abstracts).

A coulometric-titration coulometer. Stanley W. Smith and John K. Taylor. (See above abstracts).

Electron beam magnetometer. L. Marton, Lewis B. Leder, J. W. Coleman, and D. C. Schubert. (See above abstracts).

A refined X-band microwave microcalorimeter. Glenn F. Engen. (See above abstracts).

Journal of Research, Section 63D, No. 1, JulyAugust 1959. 70 cents.

Preliminary results of the National Bureau of Standards radio and ionospheric observations during the International Geophysical Year. David M. Gates.

Origin of [OI] 5577 in the airglow and the aurora. Franklin E. Roach, James W. McCaulley, and Edward Marovich. (See above abstracts). 
Comparison of absolute intensities of [OI] 5577 in the auroral and subauroral zones. F. E. Roach, J. W. McCaulley, and C. M. Purdy. (See above abstracts).

Origin of "very low-frequency emissions." R. M. Gallet and R. A. Helliwell.

Climatology of ground-based radio ducts. Bradford R. Bean.

Power requirements and choice of an optimum frequency for a worldwide standard-frequency broadcasting station. A. D. Watt and R. W. Plush.

Measurments of phase stability over a low-level tropospheric path. M. C. Thompson, Jr. and H. B. Janes.

System loss in radio wave propagation. Kenneth A. Norton.

Mode expansion in the low-frequency range for propagation through a curved startified atmosphere. H. Bremmer.

Transmission and reflection by a parallel wire grid. Martin T. Decker. (See above abstracts).

Synoptic variation of the radio refractive index. B. R. Bean and L. P. Riggs.

Low-frequency propagation paths in arctic areas. A. D. Watt, E. L. Maxwell, and E. H. Whelan.

Journal of Research, Section D. Radio Propagation, 63D, No. 2, September-October 1959. 70 cents.

Stratification in the lower ionosphere. C. Ellyett and J. F. Watts.

Effect of small irregularities on the constitutive relations for the ionosphere. K. C. Budden.

Ionospheric investigations using the sweep-frequency pulse technique at oblique incidence. V. Agy and K. Davis.

Fields in electrically short ground systems: an experimental study. A. N. Smith and T. E. Devaney.

Diffraction of electromagnetic waves by smooth obstacles for grazing angles. J. R. Wait and A. M. Conda. (See above abstracts).

Very-low-frequency radiation spectra of lightning discharges. W. L. Taylor and A. G. Jean.

Radio-wave scattering by tropospheric irregularities. A. D. Wheelon.

Study at 1046 megacycles per second of the reflection coefficient of irregular terrain at grazing angles. R. E. MeGavin and L. J. Maloney.

Synoptic study of the vertical distribution of the radio refractive index. B. R. Bean, L. P. Riggs, and J. D. Horn.

Analytical integration of the differential equation for water storage, V. M. Yevdjevich, $J$. Research NBS 63B, 43 (1959).

Climatology of ground-based radio ducts, B. R. Bean, J. Research NBS 63D, 29 (1959).

Effect of small irregularities on the constitutive relations for the ionosphere, $K$. G. Budden, J. Research NBS 63D, 135 (1959).
Fields in electrically short ground systems: an experimental study, A. N. Smith and T. E. Devaney, J. Research NBS 63D, 175 (1959).

Fractional factorial experiment designs for factors at three levels, W. S. Connor and M. Zelen, NBS Applied Math. Series 54 (May 1959).

Tables of osculatory interpolation coefficients, H. E. Salzer, NBS Applied Math. Series (May 1959).

Friction and endurance of prelubricated and unlubricated ball bearings at high speeds and extreme temperatures, $\mathrm{H}$. S. White, J. Research NBS 63C, 19 (1959).

Ionospheric investigations using the sweepfrequency pulse technique at oblique incidence, $\mathrm{V}$. Agy and K. Davis, J. Research NBS 63D, 151 (1959).

Low-frequency propagation paths in arctic areas, $\mathrm{A}$. D. Watt, E. L. Maxwell, and E. H. Whelan, J. Research NBS 63D, 99 (1959).

Measurements of phase stability over a lowlevel tropospheric path, M. C. Thompson, Jr., and H. B. Janes, J. Research NBS 63D, 45 (1959).

Mode expansion in the low-frequency range for propagation through a curved stratified atmosphere, H. Bremmer, J. Research NBS 63D, 75 (1959).

Multi-factor experiments, M. Zelen and W. S. Connor, Ind. Quality Control 15, No. 9, 1 (Mar. 1959).

On a modification of Watson's lemma, F. Oberhettinger, J. Research NBS 63B, 15 (1959).

On the theory of fading properties of a fluctuating signal imposed on a constant signal, H. Bremmer, NBS Circ. 599 (May 1959).

Origin of "very low-frequency emissions", R. M. Gallet and R. A. Helliwell, J. Research NBS 63D, 21 (1959).

Power requirements and choice of an optimum frequency for a worldwide standard-frequency broadcasting station, A. D. Watt and R. W. Plush, J. Research NBS 63D, 35 (1959).

Preliminary results of the National Bureau of Standards radio and ionospheric observations during the International Geophysical Year, D. M. Gates, J. Research NBS 63D, 1 (1959).

Principal submatrices of a full-rowed nonnegative matrix, $\mathrm{K}$. Goldberg, J. Research NBS 63B, 19 (1959). 
Radio-wave scattering by tropospheric irregularities, A. D. Wheelon, J. Research NBS 63D, 205 (1959).

Stratification in the lower ionosphere, C. Ellyett and J. M. Watts, J. Research NBS 63D, $11 \%$ (1959).

Study at 1046 megacycles per second of the reflection coefficient of irregular terrain at grazing angles, R. E. McGavin and L. J. Maloney, $J$. Research NBS 63D, 235 (1959).

Synoptic study of the vertical distribution of the radio refractive index, $B$. $R$. Bean, $L$. P. Riggs, and J. D. Horn, J. Research NBS 63D, 249 (1959).

Synoptic variation of the radio refractive index, B. R. Bean and L. P. Riggs, J. Research NBS 63D, 91 (1959).
System loss in radio-wave propagation, K. A. Norton, J. Research NBS 63D, 53 (1959).

The electromotive force method of determining ionization constants: Ionization of bisulfate ion, W. J. Hamer, (Book) The Structure of Electrolytic Solutions, edited by W. J. Hamer (John Wiley de Sons, Inc., New York, N.Y.) p. 236 (1959).

Transmission of power in radio propagation, J. R. Wait, Electronic and Radio Engr. 36, No. 4 , 146 (Apr. 1959).

Very-low-frequency radiation spectra of lightning discharges, W. L. Taylor and A. G. Jean, J. Research NBS 63D, 199 (1959).

Zeros of certain polynomials, A. J. Goldman J. Research NBS 63B, 21 (1959). 